\title{
Feeding Habits of Some Young Fish.
}

By

Marie V. Lebour, D.Sc.

Naturalist at the Plymouth Laboratory.

With two figures in the text.

\section{CONTENTS.}

Labrus bergylta

Trachinus vipera

Lophius piscatorius

Blennius ocellaris .

Blennius gattorugine

Gobius microps

Gobius Ruthensparri

Callionymus lyra .

Cyclopterus lumpus

Lepadogaster Candolli

Lepadogaster bimaculata

Lepadogaster gouani

Solea vulgaris

Solea lascaris

Rhombus lævis

Gadus merlangus

Gadus pollachius

Onos mustela

Literature

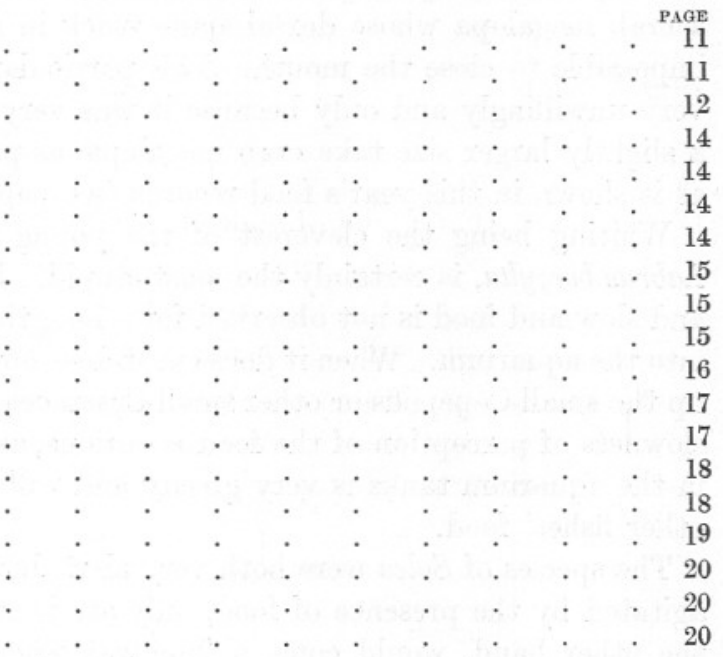

\section{INTRODUCTION.}

DURING the year 1918 several young fish brought in alive from the tow-nets were kept in small aërated aquaria at an even temperature and fed on plankton. In this way feeding habits were noted and some post-larval fish went through a metamorphosis into the adult form, notably Labrus bergylta the Ballan Wrasse, Solea vulgaris the Sole, Solea lascaris the Lemon Sole, and three species of Lepadogaster. Young Whiting and Pollack were also kept alive for some months and fed eagerly on most of the food that was given to them.

A great difference was seen in the way the various species of young fish feed. Some deliberately stalking certain selected food, others apparently eating the first thing that comes. Some feeding at all times, 
others only at night. Some eating very little at one time, others eating as much as they can get. Some very shy and only eating when apparently unobserved, others snapping immediately at the food. The Whiting, of all the young fish observed, is the greediest and very clever at recognizing the different foods and selecting the best first. The Pollack comes second. These stalk their food, usually Copepods, coming up behind and giving a sure sideways dart so that the Copepod is swallowed head first. Many times have Whiting and Pollack been captured with Copepods in their mouths, having probably swallowed these after being caught in the tow-nets when in a broad-mouthed bottle. The Copepods are always head first in the mouth, the advantage to the fish being obvious, as legs, antennæ and spines then fit close to the body and project as little as possible, whereas if the tail goes in first all would stick out, and a fish is easily choked by a spine. One small Whiting died from swallowing a crab megalopa whose dorsal spine stuck in its throat so that it was impossible to close the mouth. This particular fish took the megalopa very unwillingly and only because it was very hungry, but Whiting of a slightly larger size take crab megalopæ as part of their natural food, as is shown in this year's food records (see page 34 of this Journal).

Whiting being the cleverest of the young fish, the Ballan Wrasse, Labrus bergylta, is certainly the most stupid. Its movements are heavy and slow and food is not observed for a long time after having been put into the aquarium. When it does eat it does not stalk its food, but snaps up the small Copepods or other small Crustacea that cross its path. This slowness of perception of the food is curious, as the adult Ballan Wrasse in the aquarium tanks is very greedy and will if possible eat up all the other fishes' food.

The species of Solea were both very alert, but Solea vulgaris, although agitated by the presence of food, only ate it at night, Solea lascaris, on the other hand, would come a long way when food was put into the aquarium, and dashing in amongst it would snap quickly at it, not stalking anything, but selecting what it liked best.

Young Lump Suckers, Cyclopterus lumpus, were exceedingly intelligent. Fixed by their suckers to the glass sides of the aquarium or to the aërating tube they would know at once when food was near, instantly unfix and swim about, then selecting something specially attractive would chase it and quickly swallow it. They never snapped at food whilst they were fixed but always fed swimming. The little rock suckers, Lepadogaster spp., were the same in this way and always moved about when feeding.

Rockling Onos mustela were always shy when feeding, but would eat almost anything, Callionymus lyra the dragonet, and the gobies, Gobius spp., were also not at all particular as to the food they ate and snapped up most of what was given to them. Brill and Turbot are very dainty, 
but ate occasionally Copepods, larval Crustacea, Isopods or Amphipods. Various species of Blenny would dart after Copepods, using their long fins, but were difficult to keep alive in the small aquaria.

\section{LABRUS BERGYLTA. The Ballan Wrasse.}

Three were kept alive, one of $6 \mathrm{~mm}$. on June 12th, one of $7 \mathrm{~mm}$. on July 16th, and one of $7 \mathrm{~mm}$. on August 7th. All of these were similar to those recorded by Clark (1914) and Allen (1917) having the hind part of the tail quite free from pigment, which covers the rest of the body. Two completed their metamorphosis and showed themselves to be truly Labrus bergylta, thus proving that these authors were right in attributing the post-larval form to this species.

By June 25th the specimen of $6 \mathrm{~mm}$. had grown to $11 \mathrm{~mm}$. and had undergone its metamorphosis. On July 23rd it died, measuring $15 \mathrm{~mm}$. The second specimen died the next day and contained no food. The third specimen metamorphosed at $11 \mathrm{~mm}$. and lived until October 2nd measuring $13 \mathrm{~mm}$. Both those that lived kept at the bottom of the aquarium all through the post-larval state and seemed to try to hide away as much as possible. After metamorphosis they would swim about more, especially if feeding. Their movements were always very slow, food being taken casually and without apparent selection although in the post-larval forms from the tow-nets taken from June to August and measuring from 4 to $10 \mathrm{~mm}$. Temora longicornis was almost exclusively eaten even by the smallest, with Podon intermedius in July when it was common. In captivity Labrus bergylta would eat almost any small Copepod, Temora often being present, but also there were many Acartia clausi, Oithona similis, and Copepod nauplii of various species and Balanus nauplii which were always eaten. Calanus finmarchicus although often offered was never eaten even by the largest fish of $13 \mathrm{~mm}$. It is possible that its movements are too quick for such a sluggish creature. It is an interesting fact that oyster spat was eaten, for most of the post-]arval fish refused it. Limacina retroversa was, however, not liked and always left. After metamorphosis the food seemed to be the same as before.

\section{TRACHINUS VIPERA. LESSER WEAVER.}

Four specimens were procured alive from the tow-nets in July and August, from 6 to $30 \mathrm{~mm}$., but none lived more than a few days and they would not eat at all. One of $12 \mathrm{~mm}$. caught August 2nd, died on August 8th, and in its stomach was an adult specimen of the trematode, Derogenes varicus, full of eggs. No food was found in any of them. 


\section{LOPHIUS PISCATORIUS. ANGLER.}

A post-larval Angler occurred from the region of the Panther buoy on July 2nd, 1917. It measured $8.5 \mathrm{~mm}$. in length and was alive when

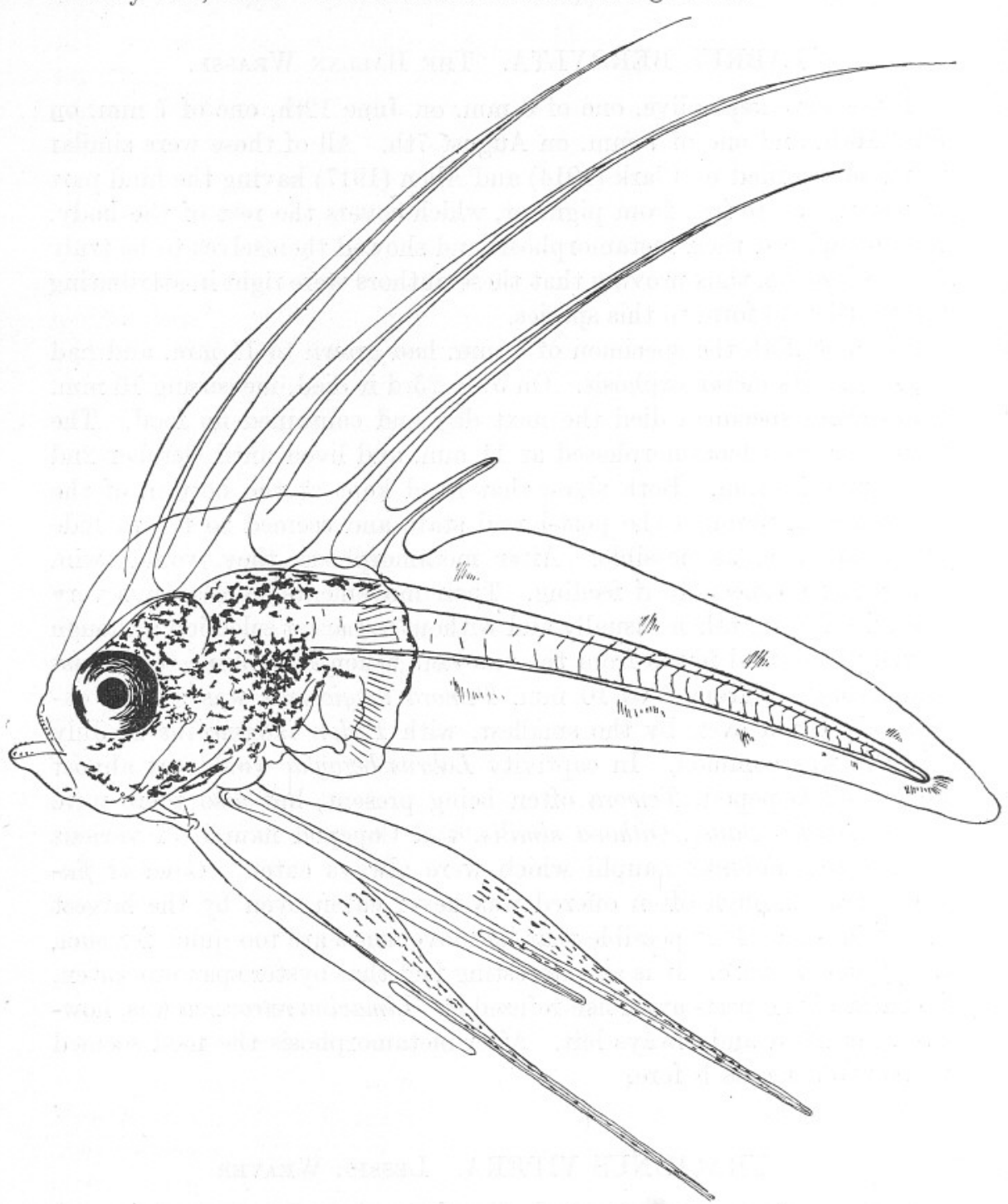

Frg. 1. Post-larval Angler, Lophius piscatorius, $8 \cdot 5 \mathrm{~mm}$. long.

brought into the Laboratory (Fig. 1). The most striking feature was its large and extremely brilliant blue eye, which glistened intensely. The yellow and black pigment of its head and fore part of the body and the 
distal portion of its pelvic fins was also conspicuous. The distribution of the pigment is peculiar, as it is entirely confined to the region from the head to the end of the alimentary canal and to the distal portions of the pelvic fins. A diffuse bright yellow pigment occurs over almost the whole of this anterior region with dense black dendritic chromatophores. The part of the head in front of the eye is almost destitute of pigment and the head crest is perfectly clear with no pigment at all. For rather more than half its length the distal end of the pelvic fin is a diffuse yellow with black chromatophores and the fringed edge of the pectoral fins are provided with small black chromatophores. Behind the anus the body is perfectly clear and hyaline.

This stage is very like the American form figured by Agassiz (1882) who, however, gives no measurements. It is older than those figured by Allen (1917) and Prince (1891), these two latter being at about the same stage and measuring over $6 \mathrm{~mm}$., and it is at a much less advanced stage than the post-larval of $7 \mathrm{~mm}$. figured by McIntosh and Prince (1890) although larger than this. The anterior portion of the dorsal fin is provided with four processes each with a supporting ray, the two front rays ending in extremely fine filaments. The pectoral fins are large with lobed edges and reach beyond the alimentary canal. The pelvic fins are much more developed than they are in the Plymouth specimen of 1917 (from 1914 tow-nets) being nearly as long as the body and having two distinct fin rays. Its shape approaches the more advanced stages figured by Agassiz (1882).

This stage follows on naturally from the younger stage from Plymouth and the oldest form figured by Prince from the Firth of Forth, the latter being 15 days old, so that probably the present specimen is a few days, older than that, perhaps three weeks old. It appears to be slightly older than Fig. 1, Pl. XVIII of Agassiz, but closely resembles this whilst the pelvic fins incline towards the shape in Fig. 2, and it exactly corresponds in colouring with Agassiz's description. There seems no reason to think, as Prince suggests, that the British Lophius is different from the American form in its post-larval stages. Danois (1913) figures a postlarval Lophius of $11 \mathrm{~mm}$. in length which is at about the same stage as Allen's and Prince's, the pelvic filaments being rather longer.

On July 2nd from the Knap five young Anglers were obtained from 4 to $5 \mathrm{~mm}$. long. These are rather younger than the Plymouth specimen recorded by Allen and figured by Mrs. Sexton (1917), having two head spines only and the clear space above the brain enormously developed. The pigment is almost entirely black with only a faint yellowish tinge, the eyes a very deep blue so that the anterior portion of the body alone is visible in the water, the little fish looking like small round masses of dark blue, the pigment being confined to the anterior portion of the body 
and the tips of the pelvic filaments. The head spines and the whole of the body behind the anus being transparent and colourless they are invisible in the water. No food was contained in any of these young Anglers and all died soon after they were brought in. The movements of these little Anglers are wonderfully beautiful and very quick, the long pelvic fins looking more like wings than anything else, and a quick darting movement being constantly kept up.

\section{BLENNIUS OCELLARIS AND BLENNIUS GATTORUGINE.}

One live Blennius ocellaris, the Butterfly Blenny, was caught on July 8th, measuring $18 \mathrm{~mm}$. It fed on various Copepods, especially Calanus and Temora, but when these were not present it would eat Acartia and other small Crustacea including Hyperia. One Blennius gattorugine of $30 \mathrm{~mm}$. caught August 12th ate similar food. Both would chase the food and dart at it with quick movements which have already been described by Garstang (1900) in the Butterfly Blenny. They both refused oyster spat.

\section{GOBIUS MICROPS.}

One Gobius microps measuring $10 \mathrm{~mm}$. was caught alive from inside the Breakwater on July 24th. On December 18th it was still alive measuring $16 \mathrm{~mm}$., and having the adult shape and colouring. It eats any small Crustacea, darting at them quickly, but not stalking them at all. At first it swam near the surface, but very soon retired to the bottom, where it stays. It usually eats up directly any Copepods given to it. When food was scarce it ate the young Limnoria, a wood-boring Isopod, oyster spat and Limacina were refused, also chopped worm.

\section{GOBIUS RUTHENSPARRI.}

One of $10 \mathrm{~mm}$. was captured on June $7 \mathrm{th}$; on December 5th it died measuring $25 \mathrm{~mm}$. and was then in all respects like the adult, having changed from the larval and very transparent condition when it was only slightly pigmented, very soon after it was put into the aquarium. The black tail spot so characteristic of the species reached its ordinary condition at about $12 \mathrm{~mm}$. Unlike Gobius microps this species does not live at the bottom but near the surface. It would eat almost anything that was given to it even including chopped worm, but the food was chiefly Copepods. Isopods 5 or $6 \mathrm{~mm}$. long were eaten, but oyster spat and Limacina were refused. 


\section{CALLIONYMUS LYRA. DRAGONET.}

Two live specimens in May and July were obtained, one $10 \mathrm{~mm}$. on May 21st, the other $7 \mathrm{~mm}$. on July $7 \mathrm{th}$. The first died July 15 th at $21 \mathrm{~mm}$., the other died October 6 th at $17 \mathrm{~mm}$. At $7 \mathrm{~mm}$. it was still a surface swimming form, but underwent metamorphosis at $9 \mathrm{~mm}$. and lived on the bottom. At the bottom they are almost invisible, looking as much like the background as possible and when food was put into the aquarium they did not come up for it, but when it went near the bottom they darted at it quickly. Calanus, Temora, Acartia and Anomolocera it took readily, also small worms, but oyster spat was, as in most cases, refused.

\section{CYCLOPTERUS LUMPUS. LUMP SUCKER.}

Five specimens were kept alive from the tow-nets in June and July measuring 10 to $25 \mathrm{~mm}$. One of $23 \mathrm{~mm}$. was caught on December 9th. All were caught among Zostera, where they feed on the small animals among the weed. They were always very alert and instantly perceived food given to them. With their large mouths they were able to catch quite large Crustacea larvæ, such as Leander nearly as long as themselves ; Crangon and Gebia larvæ, crab zoeæ and megalopæ, Isopods and Amphipods, as well as Copepods were all eagerly eaten. The Decapod larvæ were caught from the side and bitten so that they were quite incapacitated, and then swallowed. Leander is a specially difficult animal to catch because it can see all round with its long-stalked eyes, and on account of its great agility requires a specially clever fish to catch it, but the young Lump Sucker never fails and will gaily continue to catch one after the other as they are put into the aquarium. The little Lump Sucker will go for quite large Idotea, sometimes, however, attempting to eat one that is too large. It then gives it a bite and leaves it and the Idotea pretends to be dead. The fish will not go for the food unless it is actually moving, so the Idotea is safe until it has recovered and swims about again, when the fish will again chase it, and seems to enjoy its races after its food.

\section{LEPADOGASTER CANDOLLI.}

One specimen of $6 \mathrm{~mm}$. from the tow-nets on July 29th was kept alive for a few days, but died on August 2nd, measuring 6.5 mm. When caught it was bright red and yellow, the red predominating and spreading all over the ventral surface. It is one of the most brilliant of the post-larval fish. At this stage it tried to fix itself by its fins although 
no proper sucker was developed and the larval fin was still present round the tail. In the four days it underwent a metamorphosis so that the adult fins with fin rays were formed, the ventral sucker present in a rudimentary state, the colouring entirely different from the post-larval form (Fig. 2). The pigment in this later stage is arranged all over the body in irregular stripes running dorso-ventrally, the stripes themselves

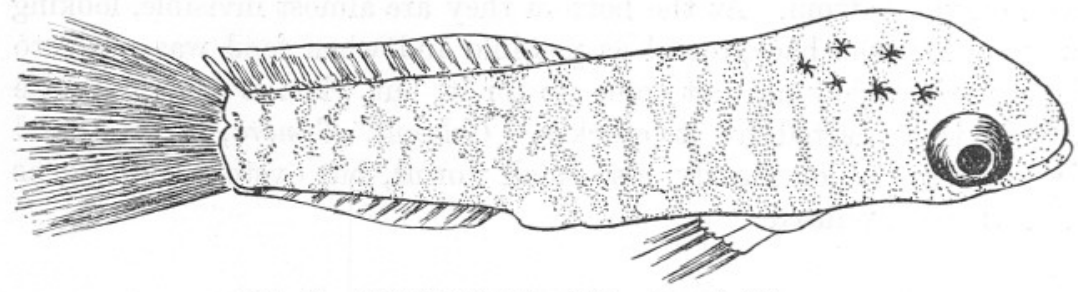

Fig. 2. Lepadogaster Candolli. Length $6.5 \mathrm{~mm}$.

formed of spots of a dull purple colour and anastomosing here and there. The characteristic starry black chromatophores on the top of the head still persist. This colouring is totally unlike the adult fish and approximates more to that of its relative Lepadogaster bimaculata, but the form of the fins shows it to belong to the present species. Its food in captivity consisted of small plankton, chiefly Copepods and Balanus nauplii, which it pursued when they came near the bottom, but it never approached the surface to feed.

\section{LEPADOGASTER BIMACULATUS.}

Two live specimens were caught in the tow-nets. The first on August 19th, measuring $6 \mathrm{~mm}$., almost immediately metamorphosed, fixing itself by its pelvic fins and the characteristic unpaired fins appearing. The colouring was at first pinkish, but after a few days it turned to a purple which was much more like that of the young Lepadogaster Candolli just described, but the blue spots are very conspicuous in the present species. It may thus be the light of the aquarium in the tank that induces this sombre colouration.

On December 4th this specimen measured $17 \mathrm{~mm}$. and was in the form of body and fins like the adult. It lives clinging to the glass either at the sides or bottom of the aquarium, but leaves its hold for feeding and darts gently after its food, which consists of small Copepods, chiefly nauplii, and the adults of Temora, Pseudocalanus and Acartia. It also ate small Isopods.

Another specimen $18 \mathrm{~mm}$. long was captured on November 30th. When first brought in it was bright red, but after living in a small aquarium on December 3rd it had changed to a dull greenish purple, 
somewhat approaching the colouring of the two above-mentioned specimens of $L$. bimaculatus and $L$. Candolli. It is evident that the colouring can change very easily.

\section{LEPADOGASTER GOUANI.}

One specimen of $6 \mathrm{~mm}$. was caught in the tow-nets on August 19th. This is the common shore form and seldom occurs in the tow-nets. It was already fixing itself and its adult fins were formed. It unfortunately died the next day.

These notes on young Lepadogaster show that the time of metamorphosis of all three species is at about $6 \mathrm{~mm}$., the permanent fins at that time being formed and fixation taking place.

\section{SOLEA VULGARIS. Common Sole.}

A Sole of $11 \mathrm{~mm}$. was kept alive from the tow-nets on April 12th and is still alive and well. When captured it had not quite completed its metamorphosis, and although inclined to settle on the bottom it sometimes swam about near the surface. Very soon, however, it settled down at the bottom of the aquarium for good. Temora was given to it for food exclusively for nearly two months. This Copepod was chosen as it was found last year to be its commonest food. It throve very well on this although never seen to eat, as it always fed at night, all the Copepods having disappeared by the next day. About 30 Temora a day were given to it, but on some days none at all. By June 3rd it was more than double the size, now measuring $25 \mathrm{~mm}$., and lying at the bottom of a flat glass aquarium with the upper part of its body a spotty sand colour. At this time as no Temora was obtainable Calanus was substituted, which was readily eaten, but, as before, always at night. On June 10th it measured $30 \mathrm{~mm}$., having grown $5 \mathrm{~mm}$. in 7 days, a few other Copepods, including Acartia clausi and Anomalocera Petersoni, being mixed with the Calanus and also eaten. After this it was given Decapod larvæ, Crangon, Leander, Gebia, Hippolyte, crab zoëæ and megalopæ, all of which it ate except the Leander, which apparently was difficult to catch. It even ate Porcellana larvæ, which are avoided by most young fish on account of the long spines. Young Hyperia and other Amphipods and young Isopods were also eaten and small live worms, but chopped worm at this stage was refused. Oyster spat was apparently uneaten. At $35 \mathrm{~mm}$. in July it jumped out of the small aquarium and was seen in the larger tank in which this was standing. As this tank was fitted with a false bottom it was difficult to reach the Sole which was seen from time to time, pieces of chopped worm being 
periodically put into the water for it. On December 4 th the false bottom was removed and the Sole rescued. It then measured $50 \mathrm{~mm}$. As the normal gr wth is about 5 inches in the first year this is rather below normal, but is easily accounted for as the fish had little food. It will now eat chopped worm and is perfectly well.

\section{SOLEA LASCARIS. Lemon Sole.}

A specimen $9 \mathrm{~mm}$. long was kept alive from the tow-nets on July 15 th. The eyes were still quite symmetrical and the fish completely in the post-larval condition, swimming vertically and pigmented on both sides. Unlike Solea vulgaris it fed in the daytime, eagerly eating Acartia clausi, Pseudocalanus and Copepod nauplii. Directly the food was put into the aquarium it would come up to it and apparently selecting what it liked best it would retire backwards, make one dart at it and swallow it. It seemed to like the nauplii best, but would eat the smaller adult Copepods. Calanus and even Temora seemed at first too big for it. On July 20th it showed signs of settling at the bottom, and by August 1st it had completely metamorphosed. It still would come up to feed, getting agitated as soon as food was put into the aquarium. As it got bigger it ate Temora and Calanus and the smaller Decapod larvæ, but could not manage Leander, Porcellana nor crab larvæ. It also refused oyster spat and Limacina. In the autumn when plankton was scarce it took small Isopods, but like Solea vulgaris it refused chopped worm. It died on November 19th measuring $23 \mathrm{~mm}$., having grown $14 \mathrm{~mm}$. in four months.

\section{RHOMBUS LAVIS. BRILL.}

One Brill of $27 \mathrm{~mm}$. on July 1st and one of $15 \mathrm{~mm}$. on July 24th were kept alive from the tow-nets. The smaller specimen died the next day having eaten 4 Anomalocera that were given to it. The other lived till October 6th when it measured $33 \mathrm{~mm}$., but it never ate very much. It was the only one of the small fish except the Lump Sucker that could take Leander larvæ, but it was slow to do this and never eager for food. It would only catch the live food if it were on or near the bottom and never rose to chase anything. Anomalocera, which was occasionally given it in numbers, it always ate, but would often leave Calanus alone for days; possibly because it was more difficult to catch. Brill of the same size were to be caught close inshore, which had all eaten young fish such as Rhamptistoma belone and Onos mustela, so that probably this specimen was pining for lack of fish food. 


\section{GADUS MERLANGUS. WhITING.}

Several young Whiting were obtained from the tow-nets. The first three on May 27th measured 16 to $19 \mathrm{~mm}$. Calanus was very common in the tow-nets just then, and nearly all the Whiting caught had been feeding on them. Many had them still in their mouths and must have been feeding in the jars after capture. The live specimens were therefore fed on Calanus, which they ate greedily and caught cleverly by stalking them and making a dart for them. They always perceived food directly it was put into the aquarium and went for it at once. However, if Pseudocalanus and Temora were put in with Calanus the fish would go for Pseudocalanus first, which bears out the fact recorded last year and corroborated this year that, although the young Whiting will eat other things, it seems to prefer Pseudocalanus if available. It would never eat a dead Copepod and always refused dead food of any kind or chopped worm. It is also very fond of Acartia and prefers it to Calanus.

On June 17th the two remaining Whiting (one having died) measured $22 \mathrm{~mm}$. ; on that day two live Whiting trom the tow-nets measuring $10 \mathrm{~mm}$. were put into the aquarium with the others and these instantly swallowed the smaller specimens and were none the worse after it. The Whiting is naturally a cannibal when it reaches a certain size, and in the food records this year (page 34 of this Journal) a Whiting of $55 \mathrm{~mm}$. is shown to have eaten another Whiting.

The next day plankton was given to the fish containing the following Crustacea in order of abundance :-

\section{Acartia clausi. \\ Calanus finmarchicus. \\ Temora longicornis. \\ Podon intermedius. \\ Larval Gebia. \\ Larval Porcellana.}

The Whiting persistently took Acartia first, and it was not until all these were eaten (and the fish hunted for them a long time) that anything else was taken; then one larval Gebia was eaten, then the Podon, Calanus and Temora in order. The Porcellana larva was not eaten at all and was still there the next morning. Evidently the long spines were too much for the Whiting.

When Copepods were scarce crab zoëæ were given to the Whiting, but they only ate these when very hungry, and occasionally choked over them. The megalopa stage was also unwillingly eaten and was the cause of death by choking of one of the fish. The other died on 
July 22nd measuring $35 \mathrm{~mm}$., having grown from 19 to $35 \mathrm{~mm}$. in less than two months. In its intestine were two full-grown specimens of the trematode Derogenes varicus with eggs; possibly the cause of death.

Other young Whiting were kept alive and behaved in a similar way as regards food. Small Hyperia were eaten when Copepods were not available, also other young Amphipods and Isopods. Oyster spat and Limacina were refused.

\section{GadUS POLLaChiUs. Pollack.}

Two young Pollack were obtained alive from the tow-nets measuring 20 and $22 \mathrm{~mm}$. on May 28th and 31st. The first died the next day, its intestine being full of Harpacticids. The other had a Calanus in its mouth and was fed on Calanus for some weeks, which it ate eagerly, stalking them in the same way as the Whiting.

The Pollack is, however, not quite so quick as the Whiting at perceiving and catching food, but will try new things more willingly. Thus it took a mouthful of chopped worm, but never took any more, and it was one of the few fish that attempted to eat oyster spat. This Pollack died on July 22nd measuring $35 \mathrm{~mm}$., with no recognizable food inside it. Another specimen, $26 \mathrm{~mm}$. long, kept alive for five days only, had inside it many Copepods, chiefly Temora, a crab megalopa and some oyster spat.

\section{ONOS MUSTELA. ROCKLING.}

Rockling rarely came in alive. One of $35 \mathrm{~mm}$. on August 12th lived till November 13th. It ate almost anything alive that was given to it except oyster spat and Limacina. When food was put into the aquarium it was at first shy, but would after some time dart at the food and swallow it quickly, eating chiefly Copepods and Decapod larvæ. It was able to catch and eat Leander larvæ and also ate crab zoëæ and megalopæ. Young Hyperia and other Amphipods and young Isopods were also eaten, and it would sometimes take chopped worm, but unwillingly. It always kept at the bottom of the aquarium except when catching its food. Young Rockling brought in from near the shore were eagerly eaten by young Brill.

\section{LITERATURE.}

1882. Agassiz, A. On the Young Stages of Osseous Fishes, Part III, p. 280 .

1917. Allen, E. J. Post-larval Teleosteans collected near Plymouth during the Summer of 1914. Jour. Mar. Biol. Assoc., N.S., Vol. XI, Part 2. 
1914. Clark, R. S. General Report on the Larval and Post-larval Teleosteans in Plymouth Waters. Jour. Mar. Biol. Assoc., N.S., Vol. X.

1913. Danois, E. le. Contribution à l'Etude systématique et biologique des Poissons de la Manche Occidentale.

1900. Garstang, W. Preliminary Experiments on the Rearing of SeaFish Larvæ. Jour. Mar. Biol. Assoc., N.S., VI, No. 1.

1917. Lebour, M. V. The Food of Post-larval Fish. Jour. Mar. Biol. Assoc., N.S., Vol. XI, No. 4.

1890. McIntosh, W. C., and Prince, E. E. On the Development and Life Histories of Teleostean Fishes. Trans. Roy. Soc. of Edinburgh, Vol. XXXV, Pt. III.

1891. Prince, $E$. Notes on the Development of the Angler-Fish (Lophius piscatorius). 9th Ann. Rep. Fish. Board for Scotland, III. 